ISSN 1678-3921

Journal homepage: www.embrapa.br/pab

For manuscript submission and journal contents, access: www.scielo.br/pab

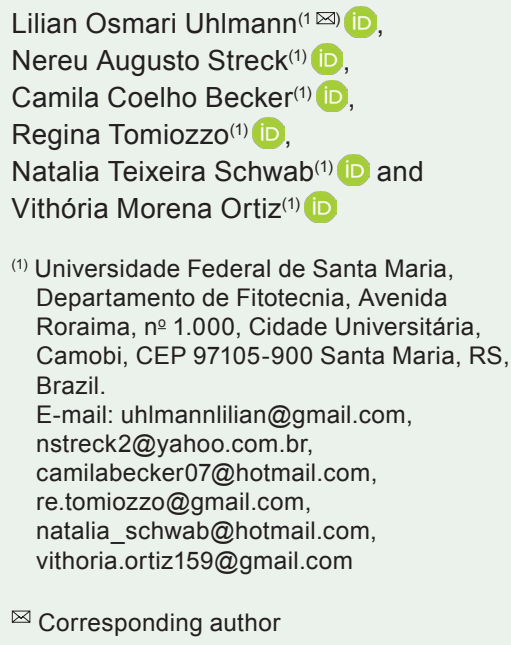

\section{Climate risk zoning for gladiolus in the state of Rio Grande do Sul, Brazil}

\begin{abstract}
The objective of this work was to develop a climate risk zoning for the gladiolus (Gladiolus x grandiflorus) crop in the 497 municipalities of the state of Rio Grande do Sul, Brazil. The PhenoGlad model was used to simulate crop development and the occurrence of damages. The model was run for four developmental cycles of gladiolus over 34 years and in 23 locations in the state. The probabilities of 10, 20, and 30\% damages due to low and high temperatures were used to define periods suitable for planting. Rio Grande do $\mathrm{Sul}$ is adequate for growing gladiolus during most of the year. In the coldest areas of the state, the inadequate planting dates are from March until midMay due to frost damage. In the hottest regions, the inadequate planting dates are greater from October to January due to heat damage. Because it is stricter, the $10 \%$ level of damage is considered more appropriate to define the periods recommended for planting.
\end{abstract}

Index terms: Gladiolus x grandiflorus, extreme temperatures, PhenoGlad, planting period, planting schedule.

\section{Zoneamento de risco climático para o gladíolo no estado do Rio Grande do Sul}

Resumo - O objetivo deste trabalho foi realizar o zoneamento de risco climático para a cultura do gladíolo (Gladiolus x grandiflorus) nos 497 municípios do estado do Rio Grande do Sul. O modelo PhenoGlad foi utilizado para simular o desenvolvimento da cultura e a ocorrência de danos. Foram realizadas rodadas com o modelo para quatro ciclos de desenvolvimento do gladíolo, ao longo de 34 anos e em 23 regiões no estado. As probabilidades de 10, 20 e $30 \%$ de ocorrência de danos por altas e baixas temperaturas foram utilizadas para definir períodos aptos para o cultivo. O Rio Grande do Sul é apto ao cultivo do gladíolo durante a maior parte do ano. Nas regiões mais frias do estado, o período inapto para o plantio ocorre de março a meados de maio devido aos danos causados pela ocorrência de geada. Nas regiões mais quentes, os períodos inaptos são maiores de outubro a janeiro devido à ocorrência de danos por altas temperaturas. Por ser mais criterioso, o nível de $10 \%$ de ocorrência de danos é considerado mais adequado para definir os períodos recomendados de plantio.

Termos para indexação: Gladiolus x grandiflorus, temperaturas extremas, PhenoGlad, época de plantio, calendário de plantio.

\section{Introduction}

The gladiolus (Gladiolus x grandiflorus Hort.), from the Iridaceae family, is one of the most important bulb-flower crops worldwide, 
standing out as a cut flower (Thakur et al., 2015). In Brazil, gladiolus is sold mainly on All Souls' Day (Schwab et al., 2015a); however, in the state of Rio Grande do Sul, its demand has increased over the years, with increased sales on different dates, such as Mother's Day and International Women's Day, and also for the ornamentation of parties and events (Schwab et al., 2018). With the increase of gladiolus consumption, cropping this cut flower has become of significant importance for small farmers. In this scenario, there is a high potential to increase local flower production and the cultivation of flowers outside the large consumer centers.

However, the expansion of gladiolus crops in the state of Rio Grande do Sul is hindered by the lack of information about the best range of planting dates during the year. This is essential since the season chosen for planting affects significantly the quality of the gladiolus spike (Ahmad et al., 2011; Akpinar \& Bulut, 2011; Schwab et al., 2015b), which needs to meet some quantitative and qualitative criteria to be accepted by the consumer market (Veilling Holambra, 2013; Schwab et al., 2015b). High temperatures, for example, affect spike quality by causing sepal burns and spike tortuosity due to wilting in the hottest period of the day (Schwab et al., 2018). However, at low temperatures, frost may be formed and kill the spike (Schwab et al., 2015b, 2018). According to Köppen's climate classification, there are two types of climate, $\mathrm{Cfa}$ (subtropical) and $\mathrm{Cfb}$ (temperate), in Rio Grande do Sul (Wrege et al., 2012). However, during winter, in the coldest region of the state, the minimum temperature can reach values below $-2^{\circ} \mathrm{C}$, whereas, during summer, in the Uruguay Valley, maximum temperatures may exceed $37^{\circ} \mathrm{C}$ (Becker et al., 2020). Therefore, since the development of gladiolus is mainly driven by air temperature (Streck et al., 2012; Schwab et al., 2015a), this variability in climate makes it difficult for farmers to plan gladiolus production throughout the year.

Models that simulate crop development can be used to define the best planting dates for different gladiolus cultivars to produce high quality spikes, as well as to define seasons and regions that present risks of damages due to low and high temperatures (Uhlmann et al., 2017). One of these is PhenoGlad, a dynamic and process-based model developed in field conditions to simulate gladiolus phenology and the effect of low and high temperatures on the floral spikes of different cultivars, in different locations and seasons (Uhlmann et al., 2017). The model uses minimum and maximum daily air temperature data to simulate the developmental stages of the crop (Schwab et al., 2015a) and also indicates damages to the gladiolus flower spike caused by high and low temperatures. In Rio Grande do Sul, the PhenoGlad model has already been used to determine the optimal planting date for gladiolus spikes to be harvested on All Souls' Day and Mother's Day, assisting growers who wish to sell this flower on special dates (Becker et al., 2020). The model simulates gladiolus phenology at potential conditions, without drought, insects, diseases, and nutritional limitations.

Climate risk zoning is the main tool used to identify the adequate seasons for planting a crop, aiming to reduce the effect of adverse climatic conditions (Cunha $\&$ Assad, 2001). There are several known studies about climate risk zoning for grain crops, such as soybean [Glycine max (L.) Merr.] (Cunha et al., 2001a; Farias et al., 2001), rice (Oryza sativa L.) (Steinmetz \& Braga, 2001), and wheat (Triticum aestivum L.) (Cunha et al., 2001b). A study on climate risk zoning and optimal planting dates for red ginger (Alpinia purpurata K.Schum) has also been carried out in the state of Pernambuco, Brazil (Medeiros et al., 2009). In the case of gladiolus, due to the demand for its flowers throughout the year, there is still the need for a climate risk zoning in Rio Grande do Sul, in order to reduce climate damage to the crop.

The objective of this work was to develop a climate risk zoning for the gladiolus crop in the 497 municipalities of the state of Rio Grande do Sul, Brazil.

\section{Materials and Methods}

The PhenoGlad model (Uhlmann et al., 2017), version 1.1, available for free download (PhenoGlad, 2020), was used to determine the adequate and inadequate periods for planting gladiolus throughout the year in the 497 municipalities of the state of Rio Grande do Sul. The model simulates different injuries considering low and high temperatures and the phenological stage of the crop, as follows. If the minimum temperature is lower than $-2^{\circ} \mathrm{C}$ for at least three consecutive days during the crop developmental cycle (DVS $=0$ to DVS $=2.0$ ), then the crop was killed by frost. If the minimum air temperature is lower than 
or equal to $-2^{\circ} \mathrm{C}$ for one day or if $-2^{\circ} \mathrm{C} \leq$ minimum temperature $\leq 3^{\circ} \mathrm{C}$ for three consecutive days during the crop's reproductive phase (DVS $>0.64$ ), then the spike was killed by frost. If the maximum temperature is greater than or equal to $34^{\circ} \mathrm{C}$ for three consecutive days from the $\mathrm{R} 1$ to the $\mathrm{R} 5$ reproductive phase (Schwab et al., 2015a), there is a risk of sunburn on flower spikes and of the three or four uppermost florets on the spike not opening.

Due to the small number of meteorological stations of Instituto Nacional de Meteorologia (INMET) in the state of Rio Grande do Sul and to a large number of data failures, the used input data were the minimum and maximum daily air temperatures obtained over 34 years (1980-2013) by Xavier et al. (2016). The authors adopted different interpolation methods to propose a high-resolution and gridded meteorological data set for all Brazil. From the grid created by Xavier et al. (2016), a total of 18 points were selected near conventional meteorological stations in Rio Grande do Sul, plus 5 more points in regions with a low density of meteorological stations, totalizing 23 grid points in the state. The municipalities were grouped into 23 homogeneous regions (Figure 1) regarding the influence of macroclimatic factors, such as altitude, latitude, continentality, maritimity, and relief (Firpo et al., 2012; Wrege et al., 2012). Different physiographic regions of the state were covered: "Litoral" (coast), "Depressão Central" (central depression), "Planalto Médio" (plateau), "Serra do Nordeste" (northeastern sierra), "Serra do Sudeste" (southeastern sierra), "Zona Sul" (southern zone), "Missões" (missions region), and "Vale do Uruguai" (Uruguay valley).

Three damage levels were evaluated (10, 20, and 30\% damage occurrence probability) in four developmental cycles (early, intermediate I, intermediate II, and late) of the crop in different regions of the state of Rio Grande do Sul (Figure 2), which were chosen due to their extreme temperatures (minimum and maximum) over the 12 months of the year (Figure 3).

The PhenoGlad model (Uhlmann et al., 2017) was run for daily planting dates from January 1 to December 31 over the 34 years and for the four gladiolus developmental cycles (Becker et al., 2020) in the 23 regions of the state of Rio Grande do Sul. The adequate and inadequate planting dates were defined by the amount of years each had with 10, 20, and $30 \%$ damage levels due to high and low temperatures

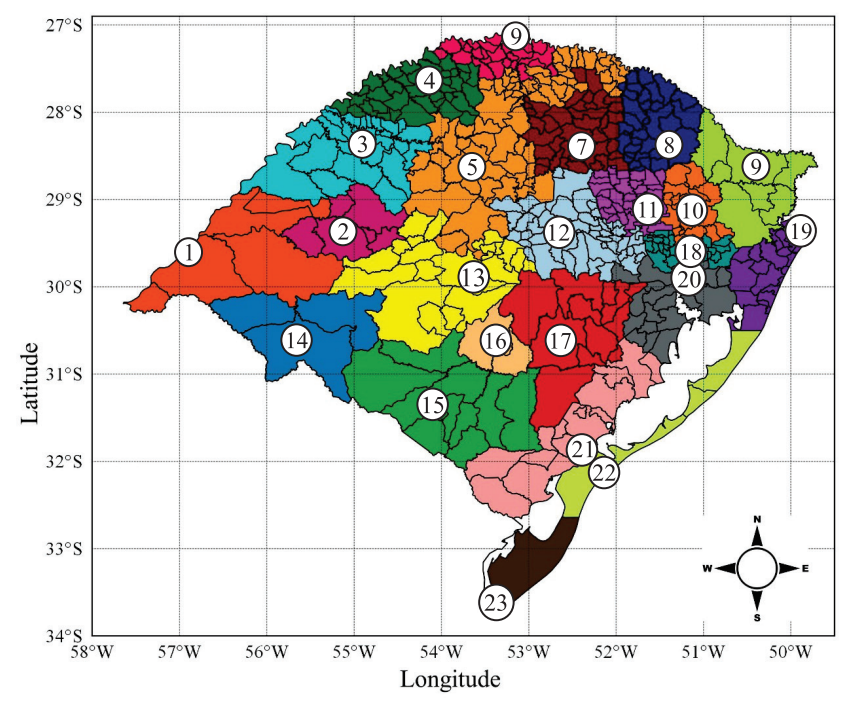

\begin{tabular}{|c|c|c|c|c|}
\hline Region & Latitude & Longitude & Tmin & Tmax \\
\hline 1 & -29.6 & -56.9 & -3.1 & 40.6 \\
\hline 2 & -29.4 & -55.1 & -2.5 & 39.4 \\
\hline 3 & -28.4 & -54.9 & -1.8 & 39.8 \\
\hline 4 & -27.6 & -54.1 & -3.1 & 38.0 \\
\hline 5 & -28.6 & -53.6 & -4.6 & 37.6 \\
\hline 6 & -27.1 & -53.1 & -2.3 & 39.0 \\
\hline 7 & -28.4 & -52.4 & -3.6 & 35.8 \\
\hline 8 & -28.4 & -51.4 & -5.1 & 35.8 \\
\hline 9 & -28.6 & -50.4 & -7.8 & 36.0 \\
\hline 10 & -29.1 & -51.1 & -3.2 & 37.7 \\
\hline 11 & -29.1 & -51.6 & -4.3 & 37.6 \\
\hline 12 & -29.4 & -52.6 & -3.2 & 37.4 \\
\hline 13 & -29.9 & -53.6 & -2.8 & 40.0 \\
\hline 14 & -30.6 & -55.6 & -3.4 & 39.4 \\
\hline 15 & -31.4 & -54.1 & -3.9 & 39.9 \\
\hline 16 & -30.6 & -53.4 & -1.5 & 38.8 \\
\hline 17 & -30.6 & -52.6 & -1.9 & 37.9 \\
\hline 18 & -29.6 & -51.1 & -2.2 & 39.9 \\
\hline 19 & -29.4 & -49.9 & -3.2 & 40.5 \\
\hline 20 & -29.9 & -51.1 & -0.5 & 39.3 \\
\hline 21 & -31.9 & -52.4 & -3.0 & 39.1 \\
\hline 22 & -32.1 & -52.1 & -2.7 & 39.4 \\
\hline 23 & -33.6 & -53.4 & -2.0 & 39.9 \\
\hline
\end{tabular}

Figure 1. Grouping of the municipalities of the state of Rio Grande do Sul, Brazil, in homogeneous regions regarding the air temperature of the historical series (1960-2013) described in Xavier et al. (2016) (A); and absolute minimum (Tmin) and maximum (Tmax) temperatures for the 23 grid points of Xavier et al. (2016) (B). 
according to the PhenoGlad model. For example, if the model indicated the occurrence of damages in $10 \%$ or more of the historical series, then the planting date was considered inadequate. The scenario that considers the level of $10 \%$ damage probability is the most restrictive, and the planting seasons and locations with less than 10,20 , or $30 \%$ of the years with risk of damages were considered adequate for planting gladiolus. The results were presented in maps using the QGIS software (QGIS Development Team, 2020 ).
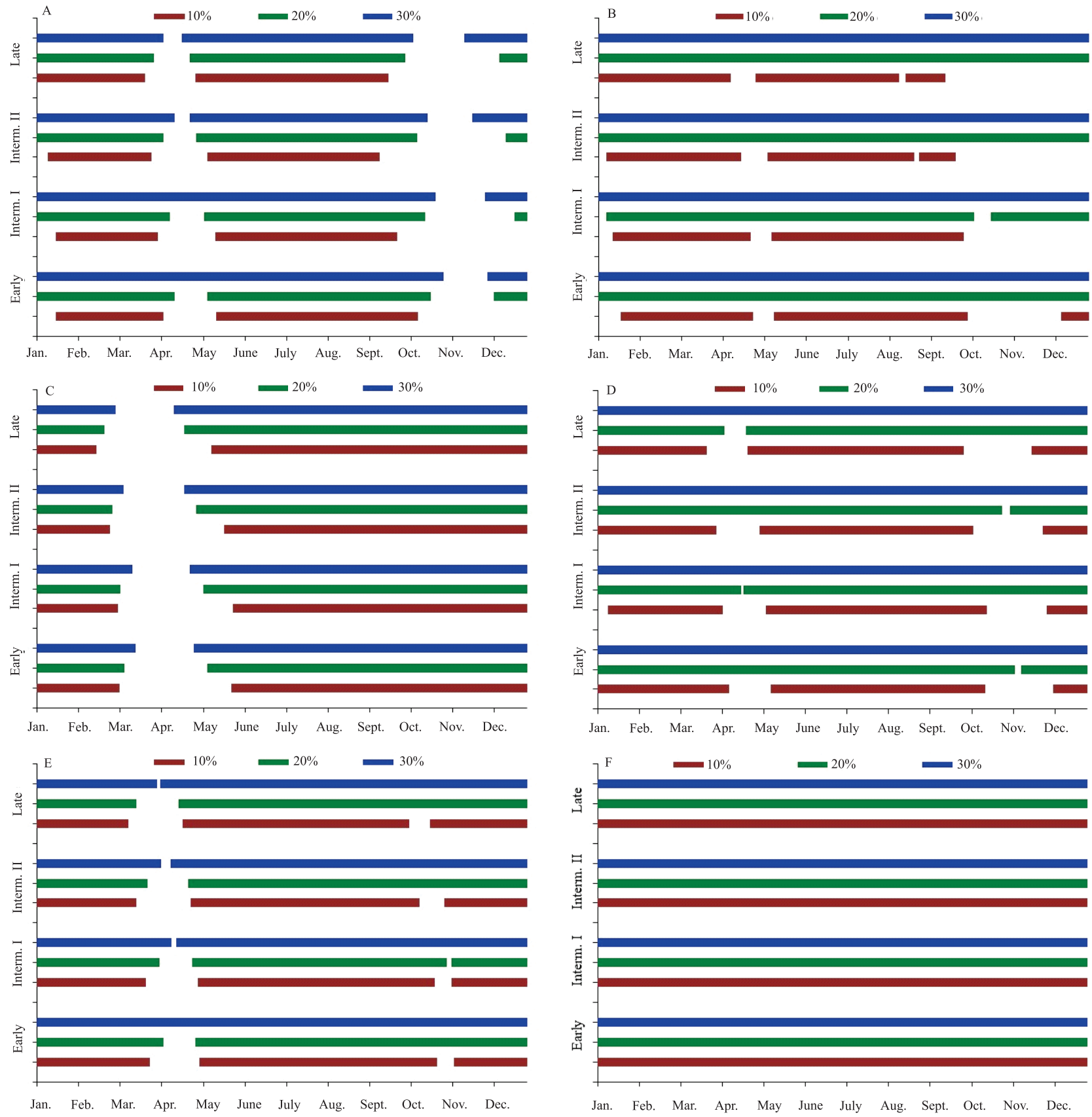

Figure 2. Adequate (colored line) and inadequate (gap) planting periods in regions 1 and 6 in the Uruguay valley (A and B, respectively), region 9 in the northeastern sierra (C), region 13 in the central depression (D), region 15 in the southern zone (E), and region 22 on the coast (F) of the state of Rio Grande do Sul, Brazil, for the damage occurrence probabilities of 10, 20 , and $30 \%$ in the historical series. 

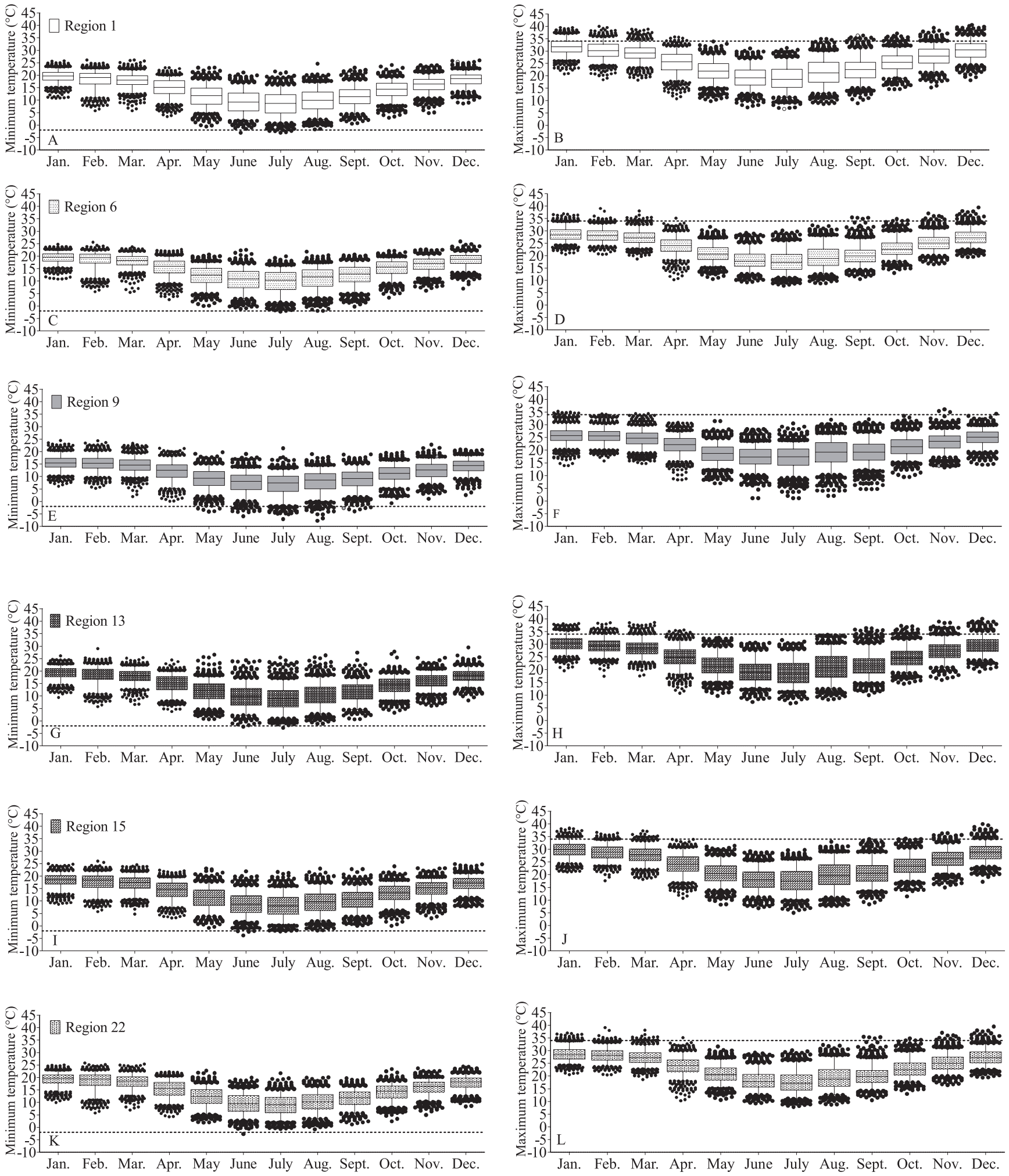

Figure 3. Minimum and maximum air temperatures throughout the 12 months of the year, from 1980 to 2013, for six regions in the state of Rio Grande do Sul, Brazil: regions 1 and 6 in the Uruguay valley (A to D), region 9 in the northeastern sierra $(\mathrm{E}$ and $\mathrm{F}$ ), region 13 in the central depression $(\mathrm{G}$ and $\mathrm{H})$, region 15 in the southern zone (I and $\mathrm{J}$ ), and region 22 on the coast ( $\mathrm{K}$ and L). In each box plot, horizontal lines represent, from bottom to top, the 5th, 25th, 50th, 75th, and 95th percentiles, and circles represent outliers. 


\section{Results and Discussion}

For the $10 \%$ level of damage, the inadequate period for planting gladiolus due to low temperature was between 88-90 days from February to May, for the different developmental cycles (Figures 2, 4, and 5). For the level of $20 \%$, the inadequate planting period varied from 64-67 days (Figures 2, 6, and 7), and, for the level of 30\%, from 47-50 days (Figures 2, 8, and 9).

The inadequate period for the $10 \%$ damage level due to high temperature was from September to January, totalizing 99-122 days for the different developmental cycles of the crop (Figures 2, 4, and 5). For the level of $20 \%$, the number of inadequate days varied from $52-$ 75 days (Figures 2, 6, and 7), and, for 30\%, from $37-$

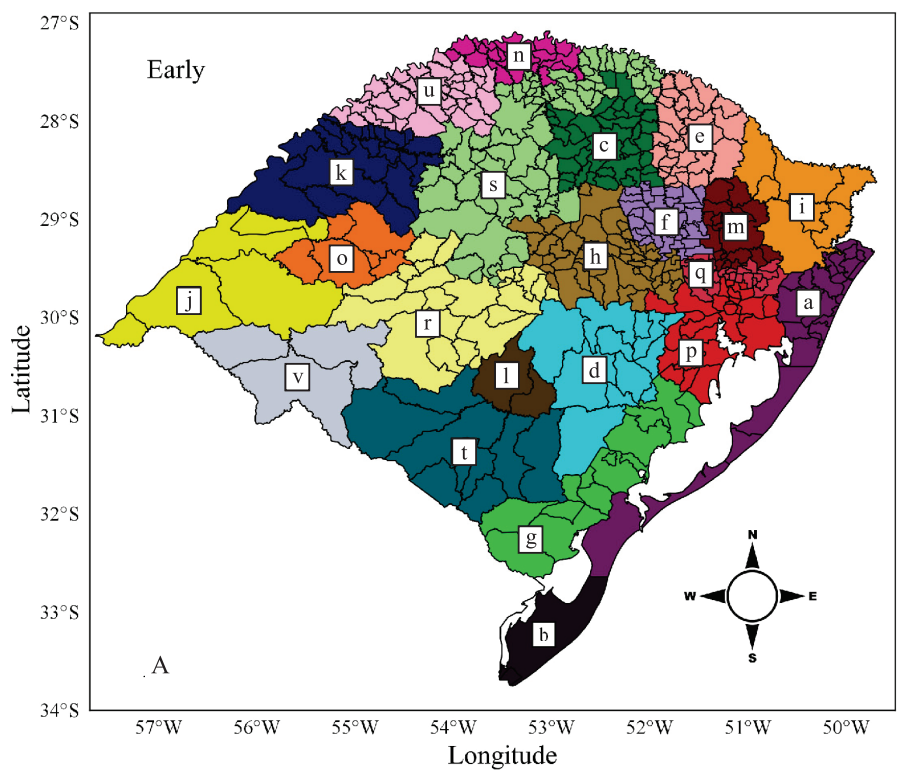

Reccomended planting dates for early cultivars

$\square$ Jan. 1 to Dec. 31 (a)

Jan. 1 to Apr. 7 and Apr. 17 to Dec. 31 (b)

Jan. 1 to Apr. 1 and May 15 to Dec. 31 (c)

Jan. 1 to Apr. 7 and May 4 to Dec. 31 (d)

Jan. 1 to Mar. 23 and May 18 to Dec. 31 (e)

Jan. 1 to Mar. 30 and May 6 to Dec. 31 (f)

Jan. 1 to Apr. 2 and Apr. 10 to Dec. 31 (g)

Jan. 1 to Apr. 1 and May 11 to Dec. 31 (h)

Jan. 1 to Feb. 27 and May 28 to Dec. 31 (i)

Jan. 17 to Apr. 1 and May 17 to Oct. 8 (j)

Jan. 17 to Apr. 21 and May 17 to Sept. 20 (k)

Jan. 1 to Apr. 9 and May 3 to Dec. 31 (l)

Jan. 1 to Apr. 3 and May 5 to Dec. 31 (m)

Jan. 20 to Apr. 22, May 14 to Sept. 29, and Dec. 14 to Dec. 31 (n)

Jan. 1 to Apr. 3, May 12 to Oct. 13, and Dec. 9 to Dec. 31 (o)

Jan. 1 to Nov. 3, Nov. 14 to Nov. 25, and Dec. 12 to Dec. 31 (p)

Jan. 1 to Apr. 5, May 5 to Nov. 4, and Nov. 11 to Dec. 31 (q)

Jan. 1 to Apr. 5, May 12 to Oct. 13, and Dec. 9 to Dec. 31 (r)

$\square$ Jan. 1 to Apr. 7, May 13 to Oct. 18 , and Nov. 14 to Dec. 31 (s)

Jan. 1 to Mar. 22, May 4 to Oct. 22, and Nov. 10 to Dec. 31 (t)

Jan. 1 to Apr. 18, May 13 to Oct. 19, and Nov. 18 to Dec. 31 (u)

Jan. 1 to Mar. 20, May 10 to Oct. 13, and Dec. 4 to Dec. 31 (v)

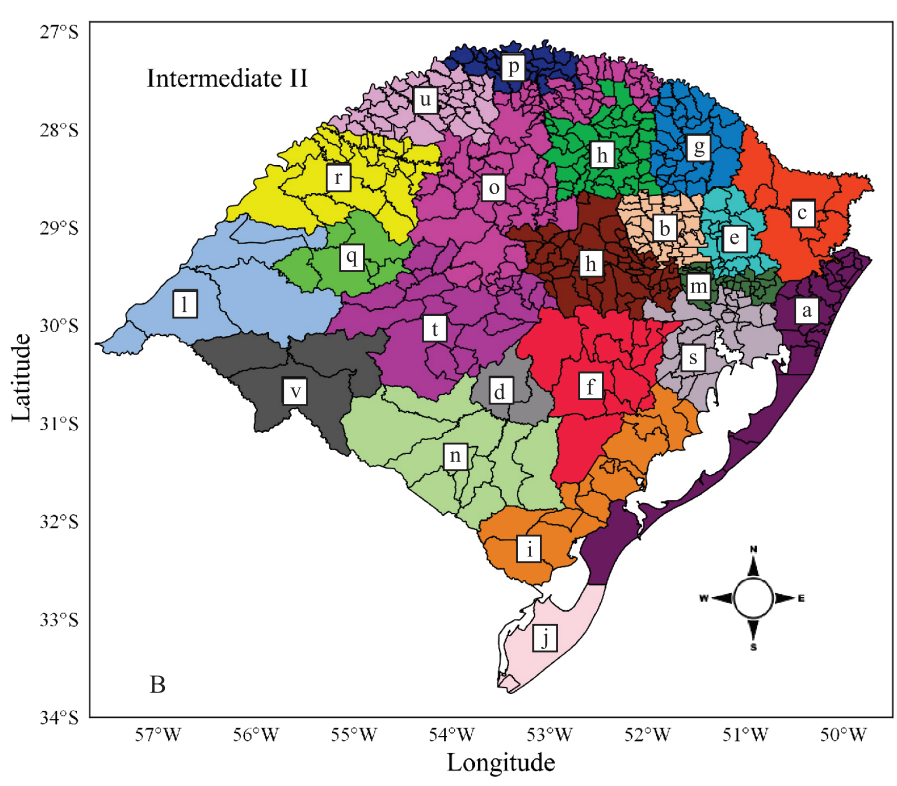

Reccomended planting dates for intermediate II cultivars

Jan. 1 to Dec. $3 \overline{1}$ (a)

Jan. 1 to Mar. 30 and Apr. 11 to Dec. 31 (b)

Jan. 1 to Feb. 20 and May 23 to Dec. 31 (c)

$\square$ Jan. 1 to Apr. 2 and Apr. 29 to Dec. 31 (d)

$\square$ Jan. 1 to Mar. 25 and Apr. 28 to Dec. 31 (e)

$\square$ Jan. 1 to Mar. 29 and Apr. 28 to Dec. 31 (f)

$\square$ Jan. 1 to Mar. 13 and May 11 to Dec. 31 (g)

Jan. 1 to Mar. 23 and May 5 to Dec. 31 (h)

Jan. 1 to Mar. 26 and Apr. 9 to Dec. 31 (i)

$\square$ Jan. 1 to Mar. 30 and Apr. 11 to Dec. 31 (j)

$\square$ Jan. 1 to Mar. 24 and May 2 to Dec. 31 (k)

$\square$ Jan. 11 to Mar. 23 and May 10 to Sept. 9 (1)

$\square$ Jan. 1 to Mar. 28, Apr. 29 to Oct. 22, and Oct. 31 to Dec. 31 (m)

$\square$ Jan. 1 to Mar. 13, Apr. 28 to Oct. 9, and Nov. 3 to Dec. 31 (n)

$\square$ Jan. 1 to Mar. 28, May 7 to Oct. 9, and Dec. 1 to Dec. 31 (o)

Jan. 9 to Apr. 13, May 9 to Aug. 20, and Aug. 30 to Sept. 20 (p)

$\square$ Jan. 1 to Mar. 27, May 4 to Oct. 4, and Dec. 5 to Dec. 31 (q)

$\square$ Jan. 9 to Apr. 14, May 10 to Aug. 19, and Sept. 5 to Sept. 14 (r)

$\square$ Jan. 1 to Oct. 22, Nov 7 to Nov 18, and Dec. 1 to Dec. 31 (s)

Jan. 1 to Mar. 26, May 4 to Oct. 4, and Dec. 1 to Dec. 31 (t)

$\square$ Jan. 1 to Apr. 10, May 7 to Oct. 1 , and Dec. 5 to Dec. 31 (u)

Jan. 1 to Mar. 14, May 2 to Oct. 1, and Nov. 26 to Dec. 31 (v)

Figure 4. Recommended planting dates for gladiolus (Gladiolus x grandiflorus) cultivars of early (A) and intermediate II (B) cycles in the state of Rio Grande do Sul, Brazil, considering 10\% damage occurrence probability. 
43 days (Figures 2, 8, and 9). These results show that the level of $10 \%$ is much more restrictive in indicating if a period is adequate or not for planting gladiolus. In Brazil, the standard used for agricultural zoning is the $20 \%$ damage level, i.e., every ten years of planting, but losses are allowed in two years (Cunha \& Assad, 2001). However, since the market demands that products, such as flowers used for ornamentation, should have a high quality to increase their acceptability by consumers, the $10 \%$ level of damage probability is more adequate to define the periods suitable for planting gladiolus in the state of Rio Grande do Sul. Damage at this level occurs only in $10 \%$ of the years, meaning that the risk of damage is lower, but planting dates are more restricted.

For the coldest areas of the state of Rio Grande do Sul, such as location 9 (Figure 1 and Figure 2 C), the inadequate period to grow gladiolus is longer

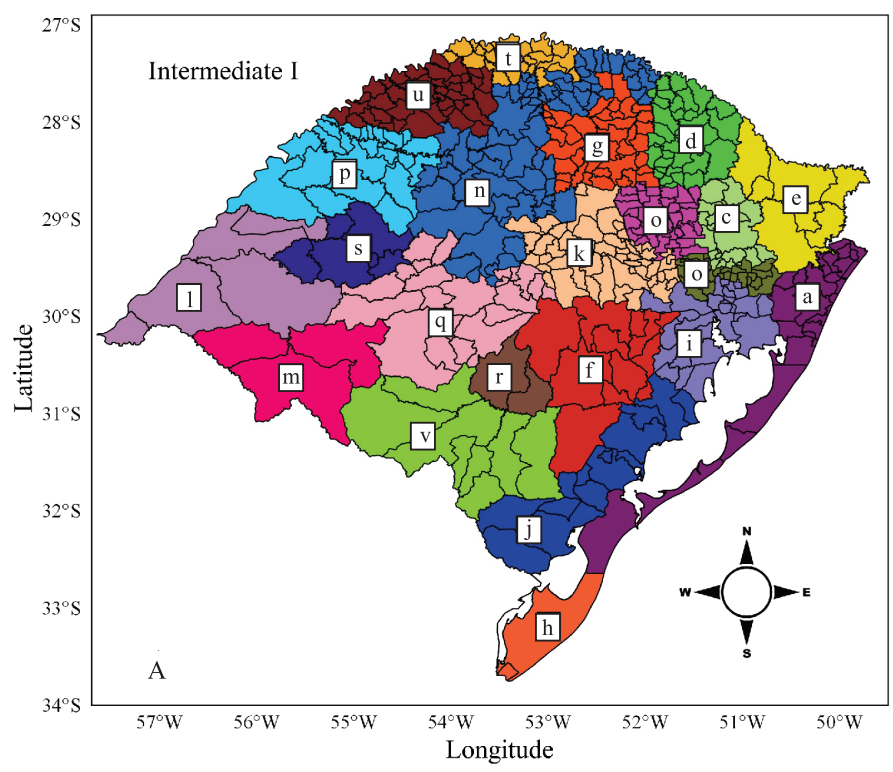

Recommendè d̄ăanting dātes för in̄termediäte I cultivars
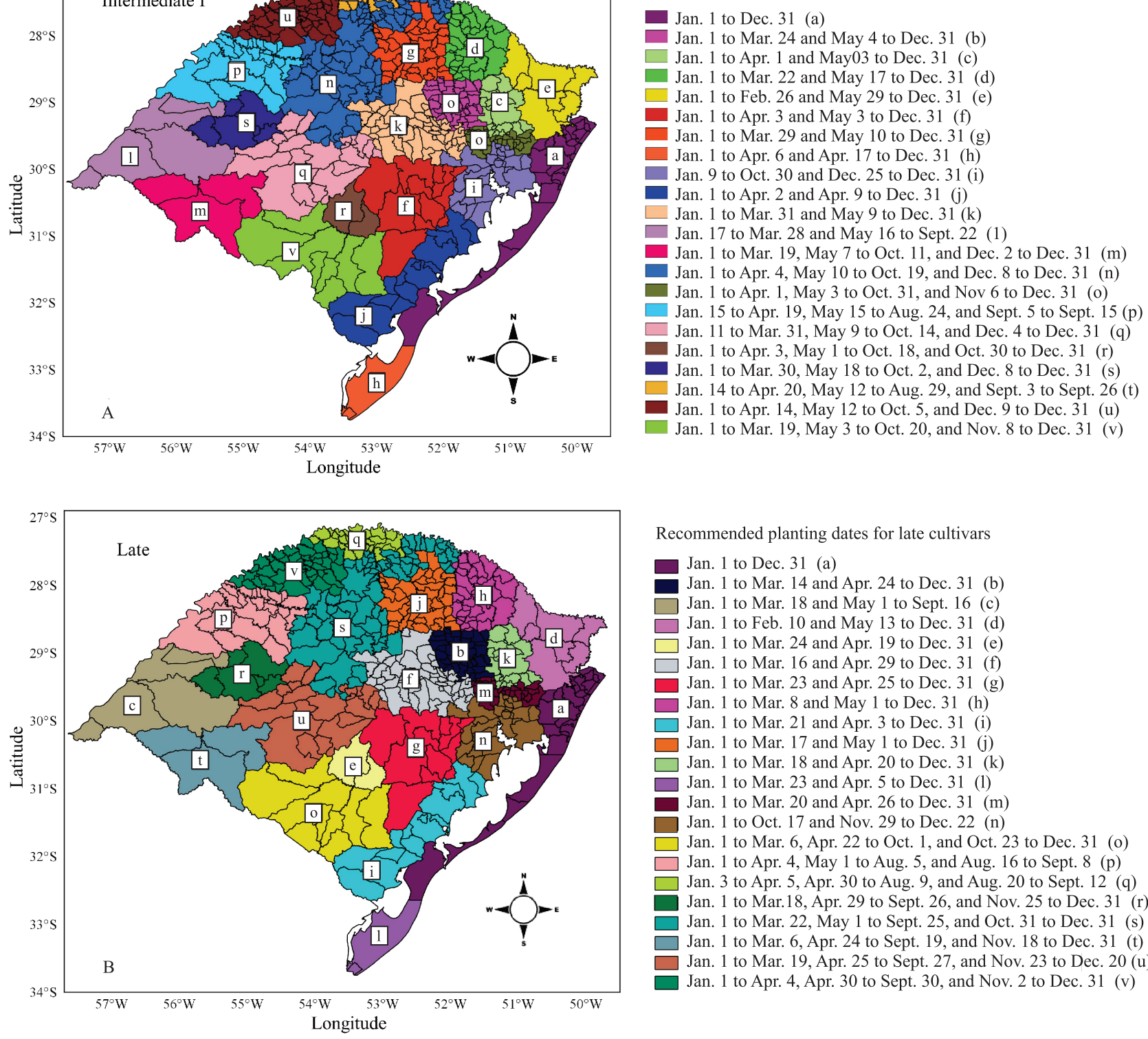

Recommended planting dates for late cultivars

Jan. 1 to Dec. 31 (a)

Jan. 1 to Mar. 14 and Apr. 24 to Dec. 31 (b)

Jan. 1 to Mar. 18 and May 1 to Sept. 16 (c)

Jan. 1 to Feb. 10 and May 13 to Dec. 31 (d)

Jan. 1 to Mar. 24 and Apr. 19 to Dec. 31 (e)

Jan. 1 to Mar. 16 and Apr. 29 to Dec. 31 (f)

Jan. 1 to Mar. 23 and Apr. 25 to Dec. 31 (g)

Jan. 1 to Mar. 8 and May 1 to Dec. 31 (h)

Jan. 1 to Mar. 21 and Apr. 3 to Dec. 31 (i)

Jan. 1 to Mar. 17 and May 1 to Dec. 31 (j)

Jan. 1 to Mar. 18 and Apr. 20 to Dec. 31 (k)

Jan. 1 to Mar. 23 and Apr. 5 to Dec. 31 (1)

Jan. 1 to Mar. 20 and Apr. 26 to Dec. 31 (m)

Jan. 1 to Oct. 17 and Nov. 29 to Dec. 22 (n)

Jan. 1 to Mar. 6, Apr. 22 to Oct. 1, and Oct. 23 to Dec. 31 (o)

Jan. 1 to Apr. 4, May 1 to Aug. 5, and Aug. 16 to Sept. 8 (p)

Jan. 3 to Apr. 5, Apr. 30 to Aug. 9, and Aug. 20 to Sept. 12 (q)

Jan. 1 to Mar.18, Apr. 29 to Sept. 26, and Nov. 25 to Dec. 31 (r)

Jan. 1 to Mar. 22, May 1 to Sept. 25, and Oct. 31 to Dec. 31 (s)

Jan. 1 to Mar. 6, Apr. 24 to Sept. 19 , and Nov. 18 to Dec. $31(\mathrm{t})$

Jan. 1 to Mar. 19, Apr. 25 to Sept. 27, and Nov. 23 to Dec. 20 (u)

Jan. 1 to Apr. 4, Apr. 30 to Sept. 30, and Nov. 2 to Dec. 31 (v)

Figure 5. Recommended planting dates for gladiolus (Gladiolus x grandiflorus) cultivars of intermediate I (A) and late (B) cycles in the state of Rio Grande do Sul, Brazil, considering 10\% damage occurrence probability. 
between March and May. This happens because, during these months, the reproductive phase of the gladiolus overlaps with the period of high probability of frost occurrence (Figure $3 \mathrm{E}$ ). For the locations with higher temperature, such as 13 (Figure $2 \mathrm{D}$ ) and 15 (Figure 2E), the risk of low temperature damage is lower (Figure $3 \mathrm{G}$ and I), resulting in longer recommended periods for planting gladiolus; however, the inadequate period due to high temperature damage is extended. These results agree with those of Schwab et al. (2018), who observed injuries due to the high air temperature of $36.2^{\circ} \mathrm{C}$ in gladiolus flower spikes in the central region of Rio Grande do Sul. These authors reported that gladiolus planted in August and September had high temperature injuries, such as temporary wilting of floral spikes and burns on the sepals of the florets,

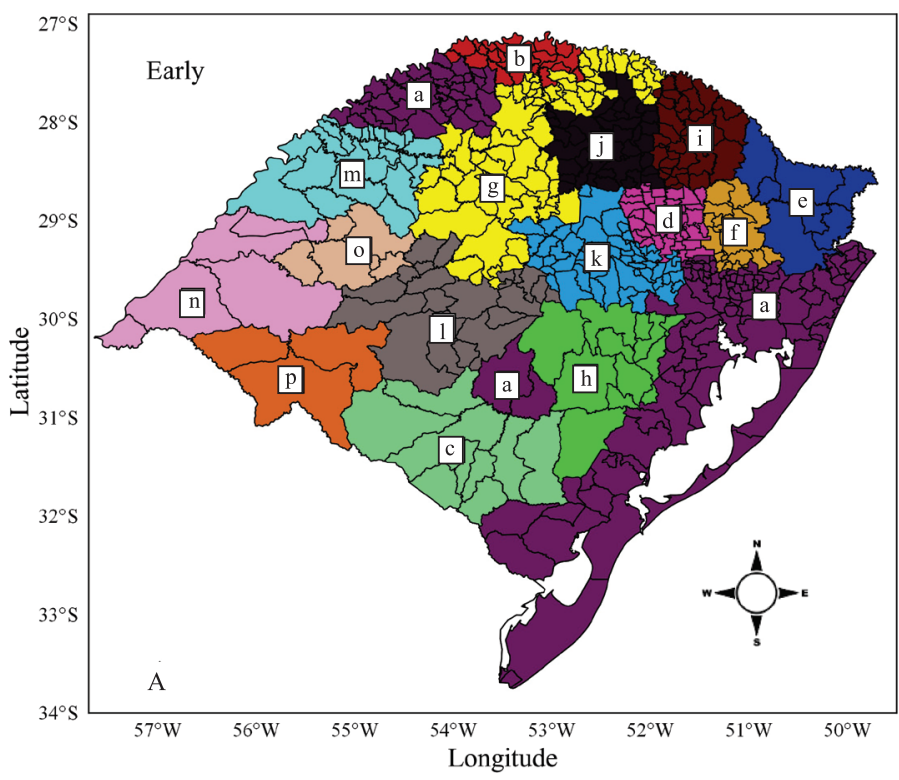

Recommended planting dates for early cultivars

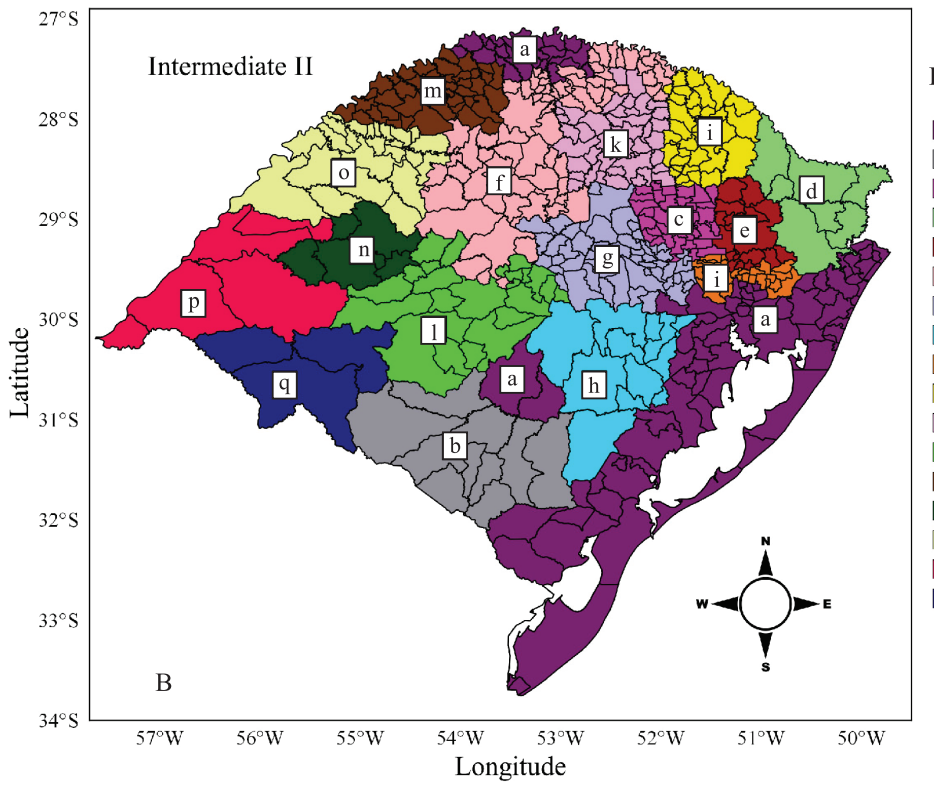

Recommended planting dates for intermediate II cultivars

Jan. 1 to Dec. 31 (a)

Jan. 1 to Mar. 20 and Apr. 26 to Dec. 31 (b)

Jan. 1 to Apr. 3 and Apr. 26 to Dec. 31 (c)

Jan. 1 to Feb. 22 and May 2 to Dec. 31 (d)

Jan. 1 to Mar. 31 and Apr. 25 to Dec. 31 (e)

Jan. 1 to Apr. 7 and May 3 to Dec. 31 (f)

Jan. 1 to Apr. 5 and Apr. 28 to Dec. 31 (g)

Jan. 1 to Apr. 5 and Apr. 25 to Dec. 31 (h)

Jan. 1 to Apr. 8 and Apr. 16 to Dec. 31 (i)

Jan. 1 to Mar. 19 and May 1 to Dec. 31 (j)

Jan. 1 to Apr. 3 and Apr. 27 to Dec. 31 (k)

Jan. 1 to Oct. 25 and Nov. 7 to Dec. 31 (l)

Jan. 1 to Apr. 16 and Apr. 30 to Dec. 31 (m)

Jan. 1 to Apr. 8, Apr. 30 to Oct. 20, and Nov. 29 to Dec. 31 (n)

Jan. 7 to Apr. 17, May 4 to Sept. 17, and Dec. 11 to Dec. 28 (o)

Jan. 1 to Apr. 1, May 2 to Oct. 7, and Dec. 19 to Dec. 31 (p)

Jan. 1 to Mar. 23, Apr. 25 to Oct. 17, and Nov. 5 to Dec. 31 (q)

Figure 6. Recommended planting dates for gladiolus (Gladiolus x grandiflorus) cultivars of early (A) and intermediate II (B) cycles in the state of Rio Grande do Sul, Brazil, considering 20\% damage occurrence probability. 
because the reproductive phase of the plants occurred during November.

The inadequate planting periods due to high temperature are longer in regions 1 and 6 in Uruguay valley (Figure $2 \mathrm{~A}$ and $\mathrm{B}$ ), which has a greater continentality influence and is the hottest region of the state of Rio Grande do Sul because of the low amount of cold fronts that pass through it (Firpo et al., 2012).
The inadequate planting period there is from October to mid-January due to the overlap of the reproductive phase of the crop with the highest probability of high temperature damage (Figure $3 \mathrm{~B}$ and D). For the 10\% level of damage, the inadequate period for planting is from 99-122 days from September to January; for the level of $20 \%$, from 52-75 days; and, for the level of $30 \%$, from $37-43$ days. Inadequate planting

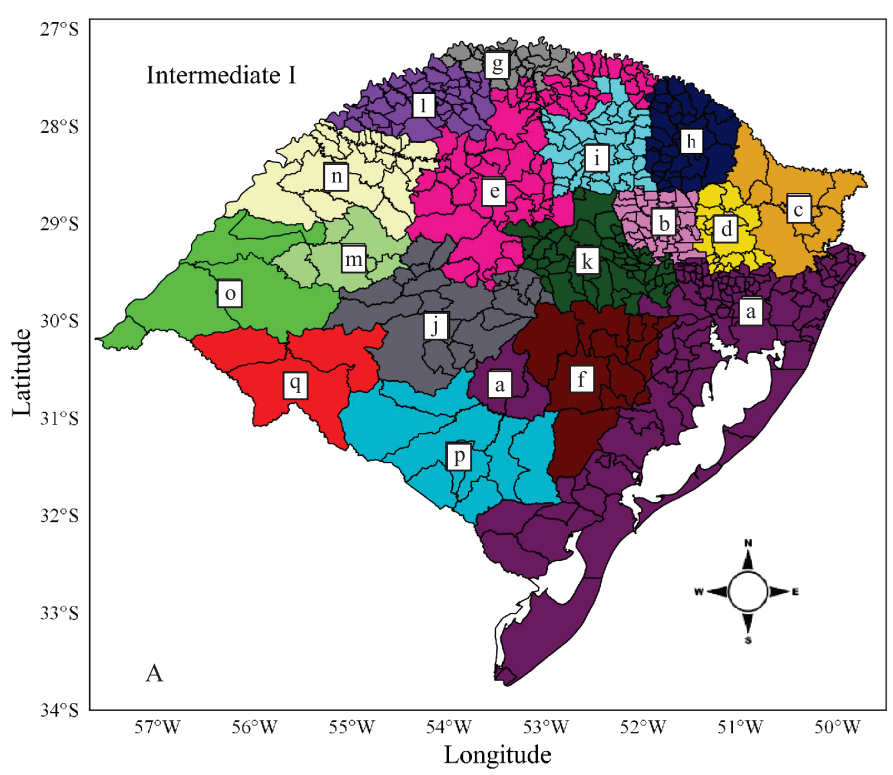

Recommended planting dates for intermediate I cultivars

Jan. 1 to Dec. 31 (a)

Jan. 1 to Apr. 9 and Apr. 29 to Dec. 31 (b)

Jan. 1 to Feb. 28 and May 7 to Dec. 31 (c)

Jan. 1 to Apr. 8 and Apr. 28 to Dec. 31 (d)

Jan. 1 to Apr. 13 and May 9 to Dec. 31 (e)

Jan. 1 to Apr. 10 and Apr. 27 to Dec. 31 (f)

Jan. 9 to Oct. 4 and Oct. 23 to Dec. 31 (g)

Jan. 1 to Mar. 24 and May 6 to Dec. 31 (h)

$\square$ Jan. 1 to Apr. 9 and May 3 to Dec. 31 (i)

Jan. 1 to Apr. 14 and Apr. 22 to Dec. 31 (j)

Jan. 1 to Apr. 11 and May 2 to Dec. 31 (k)

$\square$ Jan. 1 to Apr. 28 and May 5 to Dec. 31 (1)

$\square$ Jan. 1 to Apr. 15, May 6 to Oct. 18 , and Nov. 12 to Dec. 31 (m)

$\square$ Jan. 1 to Apr. 22, May 13 to Sept. 23, and Dec. 14 to Dec. 31 (n)

$\square$ Jan. 1 to Apr. 6, May 8 to Oct. 13, and Dec. 25 to Dec. 31 (o)

$\square$ Jan. 1 to Mar. 29, Apr. 29 to Oct. 29, and Nov. 8 to Dec. 31 (p)

$\square$ Jan. 1 to Mar. 27, Apr. 30 to Oct. 26, and Nov. 11 to Dec. 31 (q)

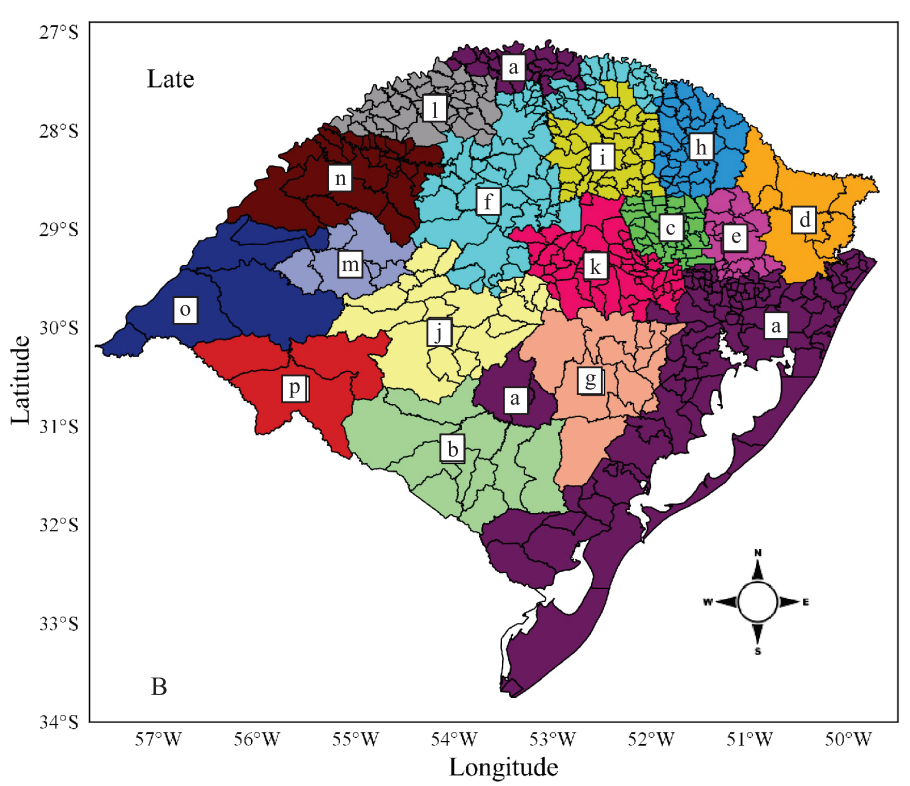

Recommended planting dates for late cultivars

Jan. 1 to Dec. 31 (a)

Jan. 1 to Mar. 12 and Apr. 19 to Dec. 31 (b)

Jan. 1 to Mar. 27 and Apr. 19 to Dec. 31 (c)

Jan. 1 to Feb. 16 and Apr. 23 to Dec. 31 (d)

Jan. 1 to Mar. 23 and Apr. 18 to Dec. 31 (e)

Jan. 1 to Mar. 29 and Apr. 25 to Dec. 31 (f)

Jan. 1 to Mar. 28 and Apr. 16 to Dec. 31 (g)

Jan. 1 to Mar. 10 and Apr. 27 to Dec. 31 (h)

Jan. 1 to Mar. 24 and Apr. 23 to Dec. 31 (i)

$\square$ Jan. 1 to Apr. 1 and Apr. 24 to Dec. 31 (j)

Jan. 1 to Mar. 29 and Apr. 21 to Dec. 31 (k)

Jan. 1 to Apr. 8 and Apr. 25 to Dec. 31 (1)

Jan. 1 to Mar. 31 , Apr. 25 to Oct. 19 , and Oct. 28 to Dec. 31 (m)

Jan. 1 to Apr. 9, Apr. 30 to Sept. 9, and Dec. 4 to Dec. 31 (n)

Jan. 1 to Mar. 25, Apr. 27 to Sept. 28, and Dec. 14 to Dec. 31 (o)

Jan. 1 to Mar. 17, Apr. 19 to Oct. 9, and Oct. 25 to Dec. 31 (p)

Figure 7. Recommended planting dates for gladiolus (Gladiolus x grandiflorus) cultivars of intermediate I (A) and late (B) cycles in the state of Rio Grande do Sul, Brazil, considering 20\% damage occurrence probability. 
periods due to heat damage reduce in the direction of region 13 in the central depression (Figure $2 \mathrm{D}$ ) and of region 15 in the southern zone (Figure $2 \mathrm{E}$ ). In Southeastern Brazil, this restriction due to high temperature was also verified for physalis (Physalis peruviana L.) cultivation (Aparecido et al., 2019). According to these authors, only $10 \%$ of the area was considered adequate for physalis production, and
$80 \%$ was inadequate because of the above-optimum temperatures.

In the central region of the state of Rio Grande do Sul, Schwab et al. (2015b) conducted experiments with monthly planting dates over two years, in order to determine the best seasons for gladiolus spikes to meet quality standards. Both quantitative and qualitative parameters were assessed, such as, respectively: total

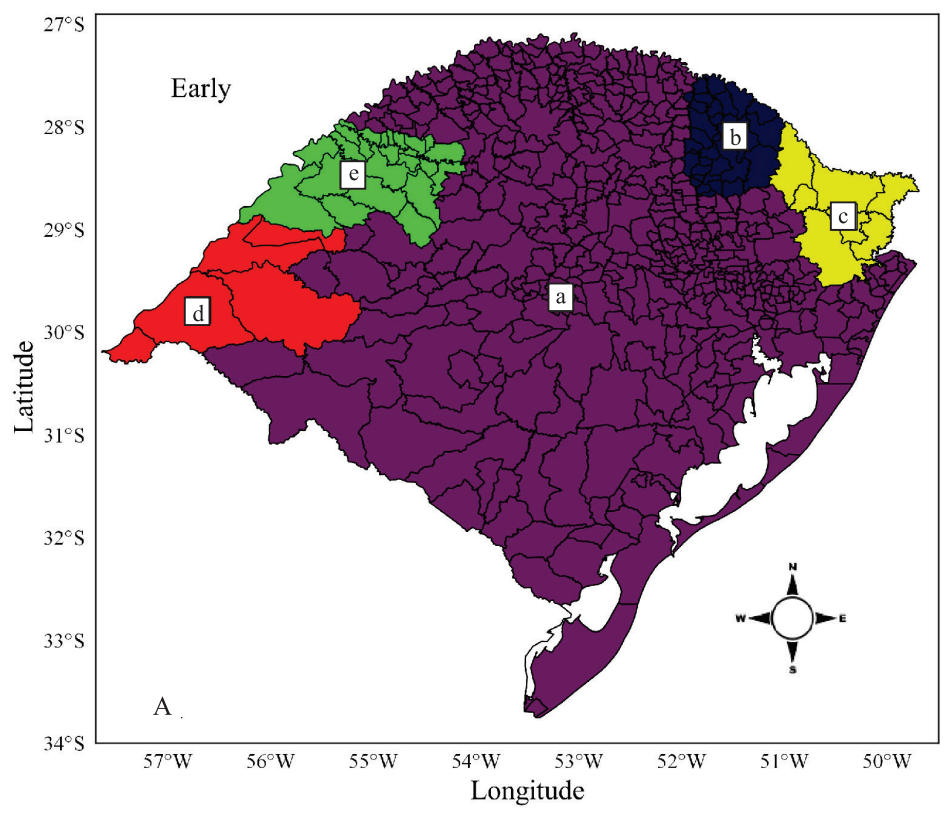

Recommended planting dates for early cultivars

Jan. 1 to Dec. 31 (a)

Jan. 1 to Apr. 8 and May 2 to Dec. 31 (b)

$\square$ Jan. 1 to Mar. 11 and Apr. 30 to Dec. 31 (c)

$\square$ Jan. 1 to Oct. 27 and Dec. 5 to Dec. 31 (d)

Jan. 1 to Oct. 14 and Nov. 23 to Dec. 31 (e)

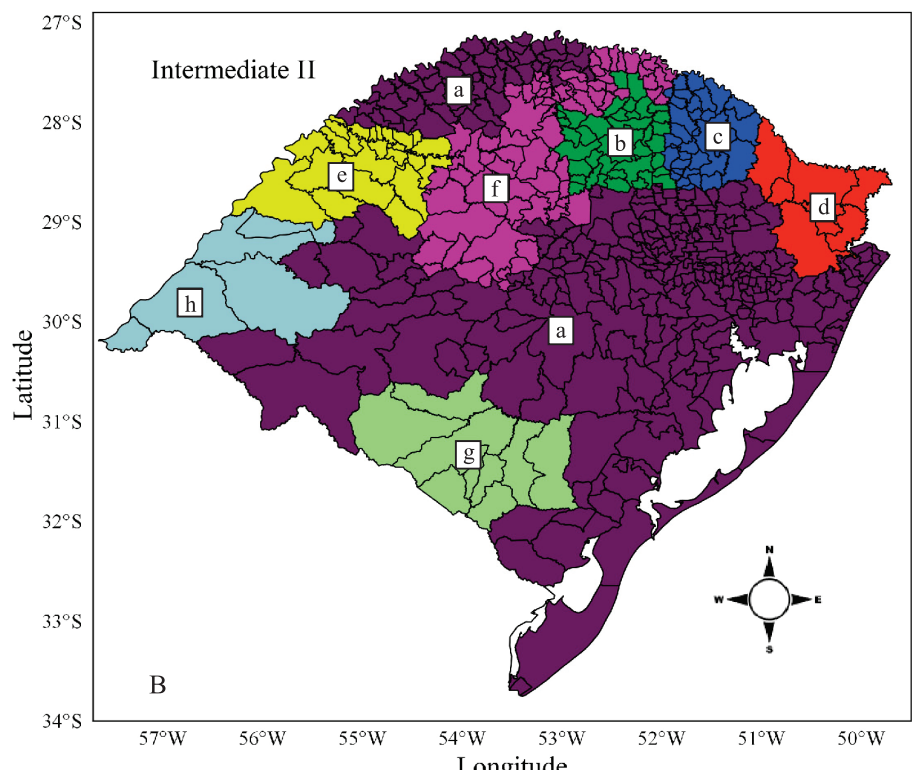

Recommended planting dates for intermediate I cultivars

Jan. 1 to Dec. 31 (a)

Jan. 1 to Apr. 7 and Apr. 24 to Dec. 31 (b)

Jan. 1 to Mar. 29 and Apr. 26 to Dec. 31 (c)

Jan. 1 to Mar. 2 and Apr. 23 to Dec. 31 (d)

$\square$ Jan. 11 to Oct. 5 and Dec. 2 to Dec. 31 (e)

$\square$ Jan. 1 to Apr. 10 and Apr. 28 to Dec. 31 (f)

$\square$ Jan. 1 to Mar. 30 and Apr. 13 to Dec. 31 (g)

$\square$ Jan. 1 to Apr. 9, Apr. 27 to Oct. 15, and Nov. 24 to Dec. 31 (h)

Figure 8. Recommended planting dates for gladiolus (Gladiolus $\mathrm{x}$ grandiflorus) cultivars of early (A) and intermediate II (B) cycles in the state of Rio Grande do Sul, Brazil, considering 30\% damage occurrence probability. 
spike length, flower spike length, and spike diameter; and visual characteristics of non-measurable spikes, including spike tortuosity, damage from diseases, and sunburn (Veilling Holambra, 2013). The best spike quality was obtained by planting gladiolus from July to September and from February to April (Schwab et al., 2015b). These results are in agreement with the one obtained in the present study (Figure 2 D), except for the lowest level of damage occurrence probability, for which mid-March onwards is considered inadequate for the cultivation of gladiolus cultivars of late and intermediate II cycles. More restrictive scenarios should be considered because, when the gladiolus is planted in inadequate periods, the critical phase of the crop will coincide with the time of low temperatures, affecting the quality of the flower spikes, which is the

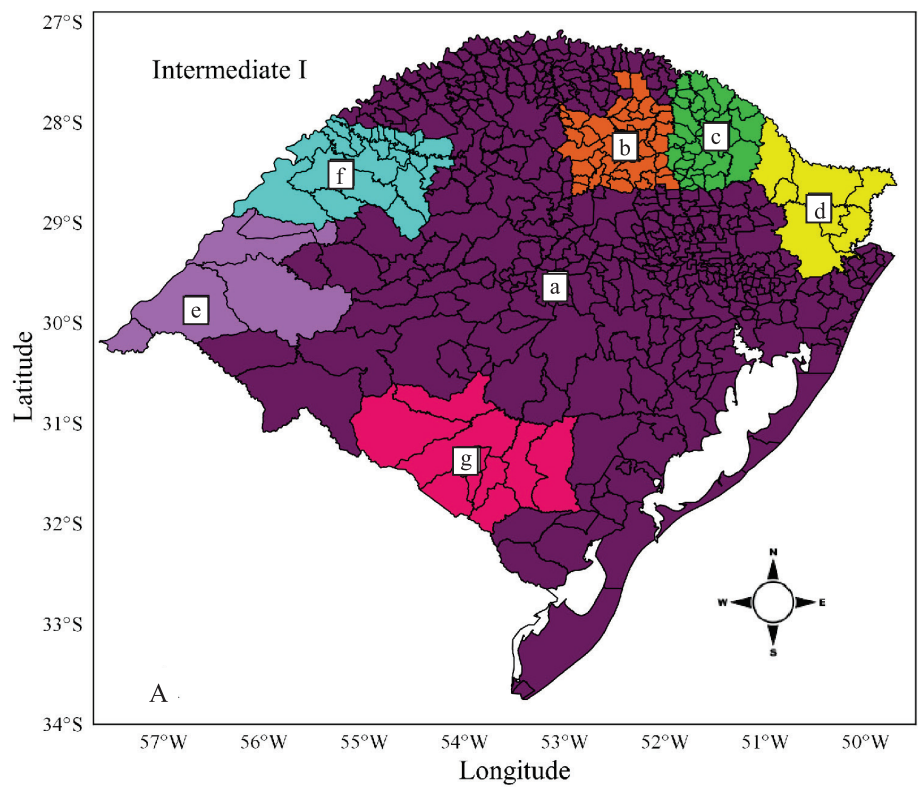

Recommended planting dates for intermediate I cultivars

Jan. 1 to Dec. 31 (a)

Jan. 1 to Apr. 13 and Apr. 30 to Dec. 31 (b)

$\square$ Jan. 1 to Apr. 5 and Apr. 30 to Dec. 31 (c)

$\square$ Jan. 1 to Mar. 9 and Apr. 27 to Dec. 31 (d)

$\square$ Jan. 1 to Oct. 21 and Dec. 3 to Dec. 31 (e)

$\square$ Jan. 1 to Oct. 11 and Dec. 6 to Dec. 31 (f)

$\square$ Jan. 1 to Apr. 7 and Apr. 17 to Dec. 31 (g)

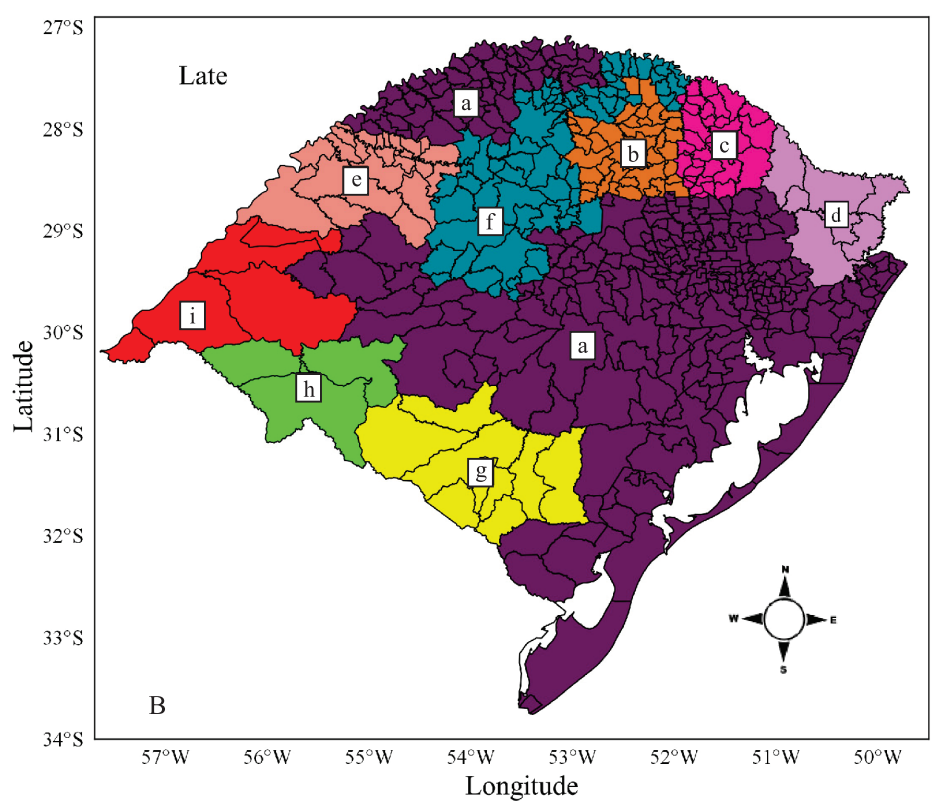

Recommended planting dates for late cultivars

Jan. 1 to Dec. 31 (a)

Jan. 1 to Mar. 31 and Apr. 17 to Dec. 31 (b)

Jan. 1 to Mar. 21 and Apr. 19 to Dec. 31 (c)

$\square$ Jan. 1 to Feb. 24 and Apr. 15 to Dec. 31 (d)

$\square$ Jan. 1 to Sept. 26 and Nov. 1 to Dec. 31 (e)

$\square$ Jan. 1 to Apr. 2 and Apr. 19 to Dec. 31 (f)

$\square$ Jan. 1 to Mar. 27 and Apr. 5 to Dec. 31 (g)

$\square$ Jan. 1 to Mar. 27 and Apr. 12 to Dec. 31 (h)

$\square$ Jan. 1 to Apr. 1, Apr. 21 to Oct. 4, and Nov. 18 to Dec. 31 (i)

Figure 9. Recommended planting dates for gladiolus (Gladiolus $\mathrm{x}$ grandiflorus) cultivars of intermediate I (A) and late (B) cycles in the state of Rio Grande do Sul, Brazil, considering 30\% damage occurrence probability. 
main component that defines the price of ornamental products (Schwab et al., 2018).

In region 22 on the coast of Rio Grande do Sul (Figure $2 \mathrm{~F}$ ), the gladiolus can be planted throughout the entire year, from January 1 to December 31, for all developmental cycles and levels of damage risk evaluated. This is because of the proximity to the Atlantic Ocean, which decreases the incidence of heat waves and of thermal amplitude due to the thermoregulatory effect of water (Firpo et al., 2012), reducing the risk of the occurrence of extreme temperatures (Figure $3 \mathrm{~K}$ and $\mathrm{L}$ ).

The inadequate planting periods for the different developmental cycles was anticipated for late, intermediate II, intermediate I, and early cycle cultivars, in this order (Becker et al., 2020). Therefore, the more advanced the developmental cycles, the earlier the inadequate planting period starts. For example, in region 15 , at the level of $10 \%$ damage occurrence probability, the inadequate planting period for late cultivars is from April 22 to October 1 and from October 23 to March 6 (Figure $2 \mathrm{E}$ ), but, for early cultivars, from May 4 to October 22 and from November 10 to March 22 (Figure $2 \mathrm{E}$ ). This is a result of the linear relationship between the lengths of the vegetative phase and of the total cycle of the gladiolus crop (Streck et al., 2012). As late cultivars take more time to enter in the reproductive phase than early ones, there is an anticipation of the inadequate planting period: 16 days earlier for the first period (autumn) and 21 days for the second (spring) in region 15 (Figure 2 E). The same behavior was observed for rice cultivars of intermediate cycle in Rio Grande do Sul, with an anticipation of 10 days in the coldest regions and of 20 days in the non-recommended planting period (Steinmetz \& Braga, 2001).

When evaluating the inadequate planting period for the four developmental cycles in region 15 , there was a trend of a longer inadequate period of 68 days for late and intermediate II cultivars, compared with that of 58 days for early cultivars (Figure 2 E). This happens because, due to their longer developmental cycle, late cultivars remain much more time in the field exposed to both low and high adverse temperatures. In practical terms, the gladiolus producers should prefer early cultivars, such as White Friendship, Purple Flora, Rose Friendship, and Amsterdam, with the shortest inadequate period for planting in the state of
Rio Grande do Sul, especially because of the shorter period they are exposed to adverse temperatures in the field (Streck et al., 2012).

The inadequate planting periods from September to January (Figure $2 \mathrm{~A}, \mathrm{~B}, \mathrm{D}$, and E) are a result of the high probability of sepals burning and of the last three to four uppermost gladiolus florets not opening (Uhlmann et al., 2017) due to high temperatures above $34^{\circ} \mathrm{C}$ during three consecutive days (Figure $3 \mathrm{~B}, \mathrm{D}$, $\mathrm{H}$, and $\mathrm{J}$ ). To reduce heat damage on the spike, it is recommend to plant gladiolus only in adequate periods or to use artificial shading over the plants during the reproductive phase, starting at R1 (Schwab et al., 2018), which allows the production of spikes over the hottest months of the year. The leaves of gladiolus, however, have been found to be extremely resistant to high temperatures, such as $40^{\circ} \mathrm{C}$ (Shillo \& Halevy, 1976; International Flower Bulb Centre, 2011), and no damage was observed during the vegetative phase of the crop in field experiments carried out over 24 months in the municipality of Santa Maria (Schwab et al., 2018), in region 13 (Figure 1).

Since floral spikes are the commercial product of gladiolus, it is very important to adopt more restrictive planting periods because low and high temperature damages decrease the quality of the final product (Schwab et al., 2018). Therefore, due to the lower risk of damaging spike quality, the $10 \%$ damage probability (Figures 4 and 5) is preferred to the levels of $20 \%$ (Figures 6 and 7 ) and 30\% (Figures 8 and 9). When the grower uses the less restrictive recommendations of 20 and $30 \%$, the probability of light or severe damage on the floral spike increases. Light damage depreciates its quality but does not evolve over time, whereas severe damage intensifies with time, restricting spike commercialization (Veilling Holambra, 2013).

For the coldest areas of the state of Rio Grande do Norte, i.e., regions 7, 8, 9, 10, 11, 12, and 17 in the northeastern sierra, plateau, and southeastern sierra (Figure 1), the inadequate planting dates for the 10\% damage occurrence probability are between March and May. Region 9, in northeastern sierra, including municipalities as Bom Jesus, Vacaria, São José dos Ausentes, São Francisco de Paula, among others, is the coldest area of the state. In this region, the inadequate planting period begins mid-February and ends midMay for cultivars of early (Figure 4 A), intermediate I

Pesq. agropec. bras., Brasília, v.55, e01094, 2020

DOI: 10.1590/S1678-3921.pab2020.v55.01094 
(Figure 5 A), and intermediate II (Figure 4 B) cycles; for late cultivars, the inadequate planting period begins in February and ends in early May (Figure 5 B). The long period of restriction in this region is attributed to the high probability of frost damage during the crop's reproductive phase, which is the most sensitive to low temperatures (Schwab et al., 2018); however, there is no risk of damage due to high temperatures in these regions of the state.

For the hottest regions of the state, i.e., 1, 2, 3, 4, 6,13 , and 20 , located in the Uruguay valley, central depression, and missions physiographic regions (Figure 1), the inadequate period for planting, for the $10 \%$ damage occurrence probability, was the longest between October and January due to the risk of heat damage. Region 1, including municipalities such as Uruguaiana, Itaqui, Alegrete, and Maçambará, is the hottest area of Rio Grande do Sul. Therefore, this region has the longest inadequate planting period in the state: beginning in September and ending in January for intermediate II cultivars (Figure $4 \mathrm{~B}$ ); beginning midSeptember and ending mid-January for intermediate I cultivars (Figure $5 \mathrm{~A}$ ); and beginning mid-October and ending mid-January for early cultivars (Figure 4 A). This inadequate planting period is due to the risk of high temperatures during the crop's reproductive phase (Figure 3 A), which causes petal burning and spike tortuosity (Schwab et al., 2018).

\section{Conclusions}

1. The gladiolus (Gladiolus $\mathrm{x}$ grandiflorus) crop can be cultivated in all 497 municipalities of the state of Rio Grande do Sul, Brazil, during most months of the year.

2. For the coldest regions of the state, located in "Serra do Nordeste" (northeastern sierra), "Planalto Central" (plateau), and "Serra do Sudeste" (southeastern sierra), the inadequate planting period is longer from March to mid-May due to the risk of frost damages during the reproductive phase of the crop.

3. For the hottest regions of the state, located in "Vale do Uruguai" (Uruguay valley), "Depressão Central" (central depression), and "Missões" (missions region), the inadequate planting period is from October to January because of the risk of sunburn on flower spikes from the R1 stage onwards.

\section{Acknowledgment}

To Conselho Nacional de Desenvolvimento Científico e Tecnológico (CNPq), for financial support (process numbers 140544/2016-0 and 302524/2011-8).

\section{References}

AHMAD, I.; KHATTAK, A.M.; ARA, N.; AMIN, N.U. Effect of planting dates on the growth of gladiolus corms in Peshawar. Sarhad Journal of Agriculture, v.27, p.195-199, 2011.

AKPINAR, E.; BULUT, Y. A study on the growth and development of some Gladiolus (Gladiolus L.) varieties planted in different time under the ecological conditions or Erzurum. African Journal of Agricultural Research, v.6, p.3143-3148, 2011.

APARECIDO, L.E. de O.; BATISTA, R.M.; MORAES, J.R. da S.C. de; COSTA, C.T.S.; MOARES-OLIVEIRA, A.F. de. Agricultural zoning of climate risk for Physalis peruviana cultivation in Southeastern Brazil. Pesquisa Agropecuária Brasileira, v.54, e00057, 2019. DOI: https://doi.org/10.1590/ S1678-3921.pab2019.v54.00057.

BECKER, C.C.; STRECK, N.A.; UHLMANN, L.O.; SILVEIRA, W.B. Scheduling optimum planting window for gladiola based on El Niño Southern Oscillation. Scientia Agricola, v.77, e20180336, 2020. DOI: https://doi.org/10.1590/1678-992X-2018-0336.

CUNHA, G.R. da.; ASSAD, E.D. Uma visão geral do número especial da RBA sobre zoneamento agrícola no Brasil. Revista Brasileira de Agrometeorologia, v.9, p.377-385, 2001. Número especial.

CUNHA, G.R. da; BARNI, N.A.; HAAS, J.C.; MALUF, J.R.T.; MATZENAUER, R.; PASINATO, A.; PIMENTEL, M.B.M.; PIRES, J.L.F. Zoneamento agrícola e época de semeadura para soja no Rio Grande do Sul. Revista Brasileira de Agrometeorologia, v.9, p.446-459, 2001a. Número especial.

CUNHA, G.R. da; HAAS, J.C.; MALUF, J.R.T.; CARAMORI, P.H.;ASSAD, E.D.;BRAGA,H.J.;ZULLOJR., J.; LAZZAROTTO, C.; GONÇALVES, S.; WREGE, M.; DRUNETA, D.; DOTTO, S.R.; PINTO, H.S.; BRUNINI, O.; THOMÉ, V.M.R.; ZAMPIERI, S.L.; PASINATO, A.; PIMENTEL, M.B.M.; PANDOLFO, C. Zoneamento agrícola e época de semeadura para trigo no Brasil. Revista Brasileira de Agrometeorologia, v.9, p.400-414, $2001 \mathrm{~b}$. Número especial.

FARIAS, J.R.B.; ASSAD, E.D.; ALMEIDA, I.R. de.; EVANGELISTA, B.A.; LAZZAROTTO, C.; NEUMAIER, N.; NEPOMUCENO, A.L. Caracterização de risco de déficit hídrico nas regiões produtoras de soja no Brasil. Revista Brasileira de Agrometeorologia, v.9, p.415-421, 2001. Número especial.

FIRPO, M.A.F.; SANSIGOLO, C.A.; ASSIS, S.V. de. Climatologia e variabilidade sazonal do número de ondas de calor e de frio no Rio Grande do Sul associadas ao ENOS. Revista Brasileira de Meteorologia, v.27, p.95-106, 2012. DOI: https://doi.org/10.1590/10.1590/S0102-77862012000100010.

INTERNATIONAL FLOWER BULB CENTRE. Gladiolus as cut flowers: guidelines for cut flower production. Hillegom, [2011]. 
MEDEIROS, S.R.R.; MOURA, G.B.A.; GIONGO, P.R.; SILVA, A.P.N. Potencial agroclimático para a Alpinia purpurata, no estado de Pernambuco. Revista Brasileira de Engenharia Agrícola e Ambiental, v.13, p.165-169, 2009. DOI: https://doi.org/10.1590/S1415-43662009000200009.

PHENOGLAD. Available at: <http://coral.ufsm.br/phenoglad/ index.php/downloads>. Accessed on: Feb. 192020.

QGIS DEVELOPMENT TEAM. QGIS Geographic Information System. Available at: <https://qgis.osgeo.org/en/site/>. Accessed on: Feb. 202020.

SCHWAB, N.T.; STRECK, N.A.; BECKER, C.C.; LANGNER, J.A.; UHLMANN, L.O.; RIBEIRO, B.S.M.R. A phenological scale for the development of Gladiolus. Annals of Applied Biology, v.166, p.496-507, 2015a. DOI: https://doi.org/10.1111/ aab.12198.

SCHWAB, N.T.; STRECK, N.A.; RIBEIRO, B.S.M.R.; BECKER, C.C.; LANGNER, J.A.; UHLMANN, L.O.; RIBAS, G.G. Parâmetros quantitativos de hastes florais de gladíolo conforme a data de plantio em ambiente subtropical. Pesquisa Agropecuária Brasileira, v.50, p.902-911, 2015b. DOI: https://doi.org//10.1590/ S0100-204X2015001000006.

SCHWAB, N.T.; STRECK, N.A.; UHLMANN, L.O.; BECKER, C.C.; RIBEIRO, B.S.M.R.; LANGNER, J.A.; TOMIOZZO, R. Duration of cycle and injuries due to heat and chilling in gladiolus as a function of planting dates. Ornamental Horticulture, v.24, p.163-173, 2018. DOI: https://doi.org/10.14295/oh.v24i2.1174.

SHILLO, R.; HALEVY, A.H. The effect of various environmental factors on flowering of gladiolus. III. Temperature and moisture. Scientia Horticulturae, v.4, p.147-155, 1976. DOI: https://doi.org/10.1016/S0304-4238(76)80006-4.
STEINMETZ, S.; BRAGA, H.J. Zoneamento de arroz irrigado por épocas de semeadura nos estados do Rio Grande do Sul e de Santa Catarina. Revista Brasileira de Agrometeorologia, v.9, p.429-438, 2001. Número especial.

STRECK, N.A.; BELLÉ, R.A.; BACKES, F.A.A.L.; GABRIEL, L.F.; UHLMANN, L.O.; BECKER, C.C. Desenvolvimento vegetativo e reprodutivo em gladíolo. Ciência Rural, v.42, p.1968-1974, 2012. DOI: https://doi.org/10.1590/S010384782012001100010.

THAKUR, T.; DHATT, K.K.; AHMED, S. Effects of planting time on growth and flowering of Gladiolus. International Journal of Current Research and Academic Review, v.3, p.145-152, 2015.

UHLMANN, L.O.; STRECK, N.A.; BECKER, C.C.; SCHWAB, N.T.; BENEDETTI, R.P.; CHARÃO, A.S.; RIBEIRO, B.S.M.R.; SILVEIRA, W.B.; BACKES, F.A.A.L.; ALBERTO, C.M.; MUTTONI, M.; PAULA, G.M. de; TOMIOZZO, R.; BOSCO, L.C.; BECKER, D. PhenoGlad: a model for simulating development in Gladiolus. European Journal of Agronomy, v.82, p.33-49, 2017. DOI: https://doi.org/10.1016/j.eja.2016.10.001.

VEILLING HOLAMBRA. Critérios de classificação: gladíolo corte. Santo Antônio de Posse: Veilling Holambra, [2013?]. 5p.

WREGE, M.S.; STEINMETZ, S.; REISSER JÚNIOR, C.; ALMEIDA, I.R. de. (Ed.). Atlas climático da região Sul do Brasil: estados do Paraná, Santa Catarina e Rio Grande do Sul. 2.ed. Brasília: Embrapa, 2012. 334p.

XAVIER, A.C.; KING, C.W.; SCANLON, B.R. Daily gridded meteorological variables in Brazil (1980-2013). International Journal of Climatology, v.36, p.2644-2659, 2016. DOI: https:// doi.org/10.1002/joc. 4518 . 